\title{
Cogongrass (Imperata cylindrica L.) Ethanol Extract on Sepsis Mice Model Body Weight and Sepsis Score
}

\author{
Mirasari Putri, ${ }^{1}$ Neni Anggraeni, ${ }^{2}$ Raden Aliya Tresna M. D., ${ }^{3}$ Ghaliby Ardhia Ramli, ${ }^{3}$ \\ Mia Kusmiati, ${ }^{1}$ Yuke Andriane, ${ }^{4}$ Eka Hendryanny, ${ }^{5}$ Abdul Hadi Hassan, ${ }^{6}$ \\ Meta Maulida Damayanti, ${ }^{6}$ Nugraha Sutadipura, ${ }^{1}$ Mas Rizky A. A. Syamsunarno ${ }^{7}$ \\ ${ }^{1}$ Department of Biochemistry, Faculty of Medicine, Universitas Islam Bandung, Bandung, Indonesia, \\ ${ }^{2}$ Medical Laboratory Technologist, Bakti Asih School of Analyst, Bandung, Indonesia, \\ ${ }^{3}$ Medical Undergraduate Study Program, Faculty of Medicine, Universitas Islam Bandung, Bandung, Indonesia, \\ ${ }^{4}$ Department of Pharmacology, Faculty of Medicine, Universitas Islam Bandung, Bandung, Indonesia, \\ ${ }^{5}$ Department of Physiology, Faculty of Medicine, Universitas Islam Bandung, Bandung, Indonesia, \\ ${ }^{6}$ Department of Pathology, Faculty of Medicine, Universitas Islam Bandung, Bandung, Indonesia, \\ 7Department of Biomedical Sciences, Faculty of Medicine, Universitas Padjadjaran, Sumedang, Indonesia
}

\begin{abstract}
Sepsis causes damage for cells, behavioral phenotype regression, and will end in most patients' death. The ethanol extract of cogongrass (Imperata cylindrica L.) root (ECGR) acts as an antioxidant. This study aimed to observe the effect of giving ECGR to body weight (BW) and the sepsis score of the sepsis mice model by lipopolysaccharide (LPS) induction. This study was an in vivo study with a randomized post-test controlled group design at the Animal Laboratory of Universitas Padjadjaran, 2018. We used 4 (four) groups of male mice (Mus musculus) DDY strains. Group 1 as a control, group 2: LPS $10 \mu \mathrm{L} / \mathrm{kgBW}$, group 3, and 4: LPS+ECGR (90 mg/kgBW, and a dose of 115 $\mathrm{mg} / \mathrm{kgBW}$, respectively). This treatment was performed for two weeks. Every three days, we measured their body weight. After two weeks, group 2, group 3, and 4 were injected with LPS for 8 hours to induce sepsis. Next, we measured body weight and sepsis score using murine sepsis score (MSS). Then statistical analysis was performed using ANOVA and the Kruskal-Wallis test. The results showed no differences in body weight were found in the treatment groups (3 and 4) compared with control, suggesting no effect of ECGR in decreasing mice body weight. The sepsis score was more than 21 in groups treated with LPS (2, 3, and 4), suggesting LPS can induce sepsis. There was a slight decrease in scores in-group 3 and 4 compared with group 2. This study concludes that the treatment of ECGR caused no harm to body weight and slightly decreased sepsis score in the sepsis mice model.
\end{abstract}

Keywords: Body weight, cogongrass, murine sepsis score, reactive oxygen species

\section{Ekstrak Etanol Alang-alang (Imperata cylindrica L.) terhadap Bobot Badan dan Skor Sepsis Mencit Model Sepsis}

\begin{abstract}
Abstrak
Sepsis menyebabkan kerusakan sel, regresi fenotipe perilaku, dan akan berakhir kematian pada sebagian besar pasien. Ekstrak etanol akar alang-alang (Imperata cylindrica L.) (ECGR) berperan sebagai antioksidan. Penelitian ini bertujuan mengetahui pengaruh pemberian ECGR terhadap bobot badan (BB) dan skor sepsis pada mencit model sepsis yang diinduksi lipopolisakarida (LPS). Penelitian ini adalah penelitian in vivo dengan desain randomized post-test controlled group di Laboratoium Hewan Universitas Padjadjaran tahun 2018. Kami menggunakan 4 (empat) kelompok mencit jantan (Mus musculus) strain DDY. Kelompok 1 sebagai kontrol, kelompok 2 diinduksi LPS $10 \mu \mathrm{L} / \mathrm{kgBB}$, kelompok 3 dan 4 diinduksi LPS+ECGR (dosis $90 \mathrm{mg} / \mathrm{kgBB}$ dan $115 \mathrm{mg} / \mathrm{kgBB}$ masing-masing). Perlakuan ini dilakukan selama 2 minggu. Setiap tiga hari dilakukan pengukuran bobot badan mencit. Setelah dua minggu, kelompok 2, kelompok 3, dan kelompok 4 diinjeksi LPS selama 8 jam untuk menginduksi sepsis. Selanjutnya, diukur bobot badan dan skor sepsis menggunakan murine sepsis score (MSS). Analisis statistik menggunakan ANOVA dan Uji Kruskal-Wallis. Hasil penelitian menunjukkan tidak terdapat perbedaan bobot badan pada kelompok perlakuan (3 dan 4) dibanding dengan kelompok kontrol yang menunjukkan ECGR tidak berpengaruh dalam menurunkan bobot badan mencit. Skor sepsis lebih dari 21 pada kelompok yang diinduksi LPS (2, 3, dan 4) menunjukkan LPS dapat menyebabkan sepsis. Terdapat sedikit penurunan skor pada kelompok 3 dan 4 dibanding dengan kelompok 2. Simpulan penelitian ini, pengobatan ECGR tidak membahayakan bobot badan dan mengakibatkan sedikit penurunan skor sepsis pada mencit model sepsis.
\end{abstract}

Kata kunci: Alang-alang, bobot badan, murine sepsis score, reactive oxygen species

Received: 30 August 2020; Revised: 19 December 2020; Accepted: 21 December 2020; Published: 31 December 2020

Correspondence: Mirasari Putri. Department of Biochemistry, Faculty of Medicine, Universitas Islam Bandung. Jln. Tamansari

No. 22, Bandung 40116, West Java, Indonesia. E-mail: mirasari.putri@unisba.ac.id 


\section{Introduction}

Incidence of severe sepsis and septic shock has continued to increase over the past 30 years, and currently, more than 750,00o cases (about 3 out of 1,000 population). ${ }^{1}$ There is life-threatening organ dysfunction in sepsis due to the host's response to the infection (inflammation). ${ }^{2-4}$ The process of organ damage will continue to occur during sepsis due to an imbalance in the redox cycle, potentially lethal organ dysfunction, and it can affect any age. ${ }^{1,5,6}$ Our previous study also found that sepsis induced by lipopolysaccharide (LPS) causes myocardial contractile dysfunction in mice. ${ }^{7}$

Cogongrass (CG) or Imperata cylindrica L. is a plant that is often considered as weeds. Nevertheless, several recent studies have shown that this plant contains phenol compounds such as flavonoids and isoeugenin. These bioactive compounds can act as a potential antiinflammatory and antioxidant. ${ }^{8-10}$

Our previous study showed ethanol extract cogongrass (Imperata cylindrica L.) root (ECGR) depressed cholesterol level and triglycerides absorption in vivo studies. ${ }^{11,12}$ In this current study, we pursued to explore the effect of ECGR in mice model sepsis, where we used LPS to induce sepsis. In this current study, we measured the body weight and the sepsis score in the sepsis mice model after treatment with ECGR.

\section{Methods}

Experimental laboratory research was conducted using a randomized post-test controlled group design. The Health Research Ethics Committee of Universitas Islam Bandung, Bandung, West Java, Indonesia, has approved the ethical clearance with number 153/Komite Etik.FKIII/2018. This study was conducted at the animal laboratory of Universitas Padjadjaran, 2018.

Cogongrass root was obtained from Solo, Central Java, Indonesia, and was tested to its authenticity by Institute Teknologi Bandung Institute, Indonesia. The roots of CG were separated and washed clean with water, dried for two weeks, then macerated, and filtered. The filtration in the extract's form was separated from the solvent by using a vacuum rotary evaporator. ECGR was diluted using carboxyl methylcellulose (CMC) $0.5 \%$ (Merck, U.S.A.) and divided in to 2 doses: $90 \mathrm{mg}$ and $115 \mathrm{mg}$ concentration/kgBW. ${ }^{11}$

The mice (Mus musculus) DDY strains with the same breed, age of 8-10 weeks with body weight (30-35 grams), were selected as objects of this study. Mice were provided by PT Bio Farma, Bandung, West Java, Indonesia. These mice were divided into four experimental groups consisting of 8 mice/group. Therefore the total of mice used in this experiment was 32 mice. Group 1 as the negative control, mice that only treated CMC $0.5 \%$ (the solvent ethanol extracts of Imperata cylindrica L. root); group 2 (CMC 0.5\%+LPS); group 3 and group 4 , mice that treated ECGR in dose $90 \mathrm{mg} / \mathrm{kgBW}$ and dose $115 \mathrm{mg} / \mathrm{kgBW}$, respectively + LPS. LPS is well known used to induce sepsis conditions in many previous types of researches..$^{13^{-15}}$

The acclimatization of animal trials preceded the experiment for seven days in the laboratory. Thus they can adapt to their environment. Mice were placed within a cage at the Animal Laboratory of Universitas Padjadjaran with a controlled room temperature (setting of 12 hours of light and 12 hours of dark). Mice were given the standard food and drinking water ad libitum.

After acclimatization, groups 1 and 2 were treated $0.5 \%$ of $\mathrm{CMC}$, groups 3 and 4 were treated ECGR+0.5\% CMC each $90 \mathrm{mg} / \mathrm{kgBW}$ and $115 \mathrm{mg} / \mathrm{kgBW}$ for two weeks. The body weight of mice was measured every three days to find out whether there was an influence of the ECGR interfered with the bodyweight of mice or not. The ECGR was given once a day for two weeks, from 3 to 5 pm. ${ }^{11}$ After two weeks of treatment, groups 2, 3, and 4 were injected LPS $10 \mathrm{mg} / \mathrm{kgBW}$ (Sigma-Aldrich, St. Louis, U.S.A.). LPS was diluted within $50 \mu \mathrm{L}$ PBS and injected intraperitoneal based on previous research. ${ }^{16}$ Next, we observed behavioral phenotype by using the murine sepsis score (MSS). There were seven variables assessed: appearance, level of consciousness, activity, response to the stimulus, posture, eyes, respiration rate, and respiration quality. The mice were in sepsis if the number of MSS in each mouse was more than 21 or had the respiratory quality or respiratory rate with a value of 3 or more. ${ }^{17}$

Statistical analyses were performed using GraphPad statistical package. Variables were summarized using the mean $\pm S D$ for normal distribution data and median+interquartile range (IQR) for skewed data. Normality distribution was assessed with the Shapiro-Wilk test. The p value was calculated using the analysis of variance (ANOVA) for normal distribution (parametric) and the Kruskal-Wallis test for skewed data 
(non-parametric). Two-tailed $\mathrm{p}$ values $<0.05$ were considered statistically significant, and $\mathrm{p}<0.01=$ very significant.

\section{Results}

First, we measured the mice's body weight before and after two weeks of treatment with ECGR. We showed no significant differences in mice's body weight after treatment between each group (36.7; $38 ; 39.5 ; 39.4)$ gram with $\mathrm{p}=0.35, \mathrm{p}>0.05$.

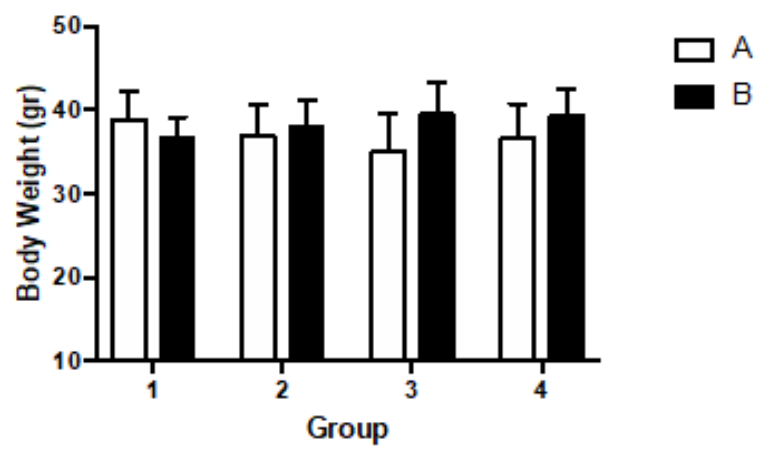

Figure 1 Bodyweight of Mice not Affected after Treatment with ECGR

$A$ and $B$, the bodyweight of mice before and after two weeks treated with ECGR, respectively. Group 1, control; 2, LPS; group 3 and 4, treated ECGR 90 and $115 \mathrm{mg} / \mathrm{kgBW},+\mathrm{LPS}$ respectively. Data in the form of mean \pm STD, $n=6-8$ /group. ANOVA with $\mathrm{p}<0.05$

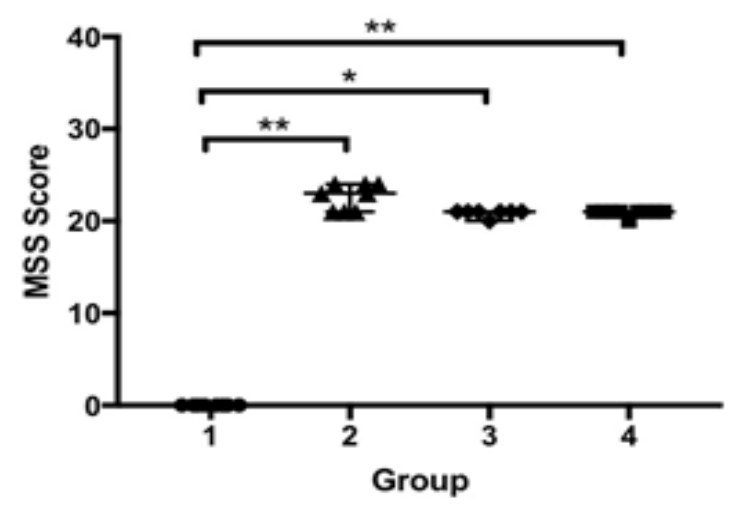

Figure 2 All Mice Treated with LPS were in Sepsis Condition

Group 1, control; 2, LPS; group 3 and 4, treated ECGR 90 and $115 \mathrm{mg} / \mathrm{kgBW}$, +LPS respectively. Data in the form of median $\pm I Q R, n=6-8$ / group, Kruskal-Walis analysis with *p<0.05 (significant); ${ }^{* *} \mathrm{p}<0.01$ (very significant)
Next, we measure the sepsis score using the MSS. Our result showed all mice in-group 2, 3 , and 4, which were treated with LPS, were in sepsis condition $(23,21,21)$, while in-group 1 (control) showed no sepsis (MSS $=0$ ). Using the Kruskal-Wallis test, we showed very significant differences in groups 2 and 4 compared with group 1 ( $\mathrm{p}=0.000 ; \mathrm{p}=0.007, \mathrm{p}<0.01$, respectively) and significant differences in group 3 compared with group $1(\mathrm{p}=0.018, \mathrm{p}<0.05)$.

\section{Discussion}

In this study, we revealed that the treatment of ECGR did not interfere with the bodyweight of the mice; moreover, ECGR also slightly reduces sepsis score in the sepsis mice model, which is induced by LPS.

We showed that ECGR did not affect mice's body weight, suggesting it does not interfere with the metabolism processes that can interfere with the bodyweight. Further study should be performed to measure body composition: fat mass, muscle mass, and body fat percentage.

MSS score is a method for assessing and comparing sepsis-associated outcomes, which consistently predicts sepsis mortality and progression in an animal model of sepsis. ${ }^{17-19}$ Using this score, in the current study, LPS increased MSS score of more than 21, suggesting LPS can induce sepsis. This result supported several previous studies. ${ }^{13-15,20,21}$

Lipopolysaccharide (LPS) is an endotoxin located outside of the gram-negative bacteria membrane ${ }^{22}$ and one of the infection stimuli that is well known to be used in experiments in causing many profound immunological responses of the host; one mechanism the toll-like receptor (TLR) 4 pathway. ${ }^{1,15}$

ECGR also slightly reduces sepsis score in the sepsis mice model, suggesting the possible role of ECGR maybe in some mechanisms in sepsis condition. The pathogenesis of sepsis involves the formation of reactive oxygen species (ROS). Endotoxins produced during sepsis, are capable of inducing ROS formation, such s superoxide, hydrogen peroxide, and hydroxyl. ${ }^{23}$ This ROS production will cause significant structural changes in the cell and ultimately cause multiple organ dysfunctions. ${ }^{24}$ Flavonoids in the ECGR play a role in the mechanism of ROS inhibition. ${ }^{8}$ Flavonoids work as an anti-inflammatory by inhibiting interleukin eight formations so that 
the recruitment process of polymorphonuclear (PMN) cells to inflamed tissues can be inhibited. ${ }^{25}$ The flavonoids in the ECGR can also act as nitrite oxide (NO) scavenging, thereby reducing NO levels. Isoeugeunin found in Imperata roots can also inhibit inducible nitric oxide synthase (iNOS) so that the formation of NO free radicals can be suppressed. ${ }^{9}$ Our next project is to explore some possible mechanisms of the potential role of ECGR in sepsis condition.

Also, we also observed the mice's behavioral phenotype by observing that mice in-group 1 had normal activities, such as eating, running, drinking, and other activities. On the contrary, the mice in group 2 showed suppressed activities, and most of the mice looked stationary. In-group 3 and 4 showed suppressing activities but more active than group 2, suggesting the potential effect of ECGR in improving the behavioral phenotype of mice induced by LPS.

\section{Conclusion}

The treatment of ECGR caused no effect on body weight and slightly decreased sepsis score in the sepsis mice model.

\section{Conflict of Interest}

The authors have read the manuscript and agreed to submit it in its current form for publication in the journal. There are no conflicts of interest to declare.

\section{Acknowledgments}

This work was supported in part by a grant from the Lembaga Penelitian dan Pengabdian kepada Masyarakat (LPPM) Universitas Islam Bandung and a grant from Faculty of Medicine, Universitas Islam Bandung, Indonesia.

\section{References}

1. Munford RS. Severe sepsis and septic shock. In: Kasper DL, Fauci AS, Hauser SL, Longo DL, Jameson JL, Loscalzo J, editors. Harrison's principles of internal medicine. $19^{\text {th }}$ edition. New York: McGraw-Hill Education; 2015. p. 1751-2.

2. Kumar V. Toll-like receptors in sepsisassociated cytokine storm and their endogenous negative regulators as future immunomodulatory targets. Int Immunopharmacol. 2020;89(Pt B):107087.

3. Murao A, Brenner M, Aziz M, Wang P. Exosomes in sepsis. Front Immunol. 2020;11:2140.

4. Hafidz A, Yuniati T, Solek P. Neopterin serum sebagai prediktor dini luaran perburukan pada sepsis neonatorum. GMHC. 2017;5(3):241-6.

5. Andrades MÉ, Morina A, Spasić S, Spasojević I. Bench-to-bedside review: sepsis - from the redox point of view. Crit Care. 2011;15(5):230.

6. Suryani YD, Prasetyo D, Hilmanto D. Fecal calprotectin in preterm infants sepsis with and without necrotizing enterocolitis symptoms. GMHC. 2018;6(3):188-92.

7. Umbarawan $\mathrm{Y}$, Syamsunarno MRAA, Obinata H, Yamaguchi A, Sunaga H, Matsui $\mathrm{H}$, et al. Robust suppression of cardiac energy catabolism with marked accumulation of energy substrates during lipopolysaccharideinduced cardiac dysfunction in mice. Metabolism. 2017;77:47-57.

8. Dhianawaty D, Ruslin. Kandungan total polifenol dan aktivitas antioksidan dari ekstrak metanol akar Imperata cylindrica (L) Beauv. (alang-alang). MKB. 2015;47(1):60-4.

9. An HJ, Nugroho A, Song BM, Park HJ. Isoeugenin, a novel nitric oxide synthase inhibitor isolated from the rhizomes of Imperata cylindrica. Molecules. 2015;20(12):21336-45.

10. Padma R, Parvathy NG, Renjith V, Rahate KP. Quantitative estimation of tannins, phenols and antioxidant activity of methanolic extract of Imperata cylindrica. Int J Res Pharm Sci. 2013;4(1):73-7.

11. Anggraeni N, Syamsunarno MRAA, Mukarromah GR, Zada A, Triatin RD, Pamela Y, et al. Low serum cholesterol in mice pre-treated with Imperata cylindrica L. after acute olive oil gavage. KnE Life Sci. 2017;2017:460-7.

12. Syamsunarno MRAA, Mukarromah G, Achadiyani A, Djunaedi D, Putri M. The use of ethanolic extract of cogongrass roots to reduce triglyceride absorption in male mice. In: Abdullah AG, Widiaty I, Abdullah CU, editors. Medical Technology and Environmental Health: Proceedings of the Medicine and Global Health Research Symposium (MoRes 2019); 2019 October 22-23; Bandung, Indonesia. Leiden: CRC 
Press/Balkema; 2020. p. 205-8.

13. Ge $\mathrm{Y}, \mathrm{Xu} \mathrm{X}$, Liang $\mathrm{Q}, \mathrm{Xu} \mathrm{Y}$, Huang M. a-Mangostin suppresses NLRP3 inflammasome activation via promoting autophagy in LPS-stimulated murine macrophages and protects against CLPinduced sepsis in mice. Inflamm Res. 2019;68(6):471-9.

14. Gupta S, Khajuria V, Wani A, Nalli Y, Bhagat A, Ali A, et al. Murrayanine attenuates lipopolysaccharide-induced inflammation and protects mice from sepsis-associated organ failure. Basic Clin Pharmacol Toxicol. 2019;124(4):351-9.

15. Hoogland ICM, Houbolt C, van Westerloo DJ, van Gool WA, van de Beek D. Systemic inflammation and microglial activation: systematic review of animal experiments. $J$ Neuroinflamm. 2015;12:114.

16. Li J, Xia K, Xiong M, Wang X, Yan N. Effects of sepsis on the metabolism of sphingomyelin and cholesterol in mice with liver dysfunction. Exp Ther Med. 2017;14(6):5635-40.

17. Shrum B, Anantha RV, Xu SX, Donnelly M, Haeryfar SMM, McCormick JK, et al. A robust scoring system to evaluate sepsis severity in an animal model. BMC Res Notes. 2014;7:233.

18. Moraes PADD, Tannuri ACA, Rios LM, Paes VR, Gonçalves JDO, Serafini S, et al. Sepsis and cirrhosis in growing animals: description of a new experimental model and its pathological and immunological reliability. Clinics (Sao Paulo). 2020;75:e1858.

19. Hassan FI, Didari T, Baeeri M, Gholami M, Haghi-Aminjan H, Khalid M, et al. Metformin attenuates brain injury by inhibiting inflammation and regulating tight junction proteins in septic rats. Cell J. 2020;22(Suppl 1):29-37.

20. Wu M, Chen W, Yu X, Ding D, Zhang W, Hua $\mathrm{H}$, et al. Celastrol aggravates LPS-induced inflammation and injuries of liver and kidney in mice. Am J Transl Res. 2018;10(7):207886.

21. Płóciennikowska A, Hromada-Judycka A, Borzęcka K, Kwiatkowska K. Co-operation of TLR4 and raft proteins in LPS-induced proinflammatory signaling. Cell Mol Life Sci. 2015;72(3):557-81.

22. Holst O. Structure of the lipopolysaccharide core region. In: Knirel YA, Valvano MA, editors. Bacterial lipopolysaccharides: structure, chemical synthesis, biogenesis and interaction with host cells. Vienna: SpringerVerlag/Wien; 2011. p. 21-39.

23. TsolakiV,MakrisD, MantzarlisK,Zakynthinos E. Sepsis-induced cardiomyopathy: oxidative implications in the initiation and resolution of the damage. Oxid Med Cel Longev. 2017;2017:7393525.

24. Matsuno $K$, Iwata $K$, Matsumoto $M$, Katsuyama M, Cui W, Murata A, et al. NOX1/ $\mathrm{NADPH}$ oxidase is involved in endotoxininduced cardiomyocyte apoptosis. Free Radic Biol Med. 2012;53(9):1718-28.

25. Rathee P, Chaudhary H, Rathee S, Rathee D, Kumar V, Kohli K. Mechanism of action of flavonoids as anti-inflammatory agents: a review. Inflamm Allergy Drug Targets. 2009;8(3):229-35. 